\title{
ANALISIS DAMPAK BELANJA LANGSUNG TERHADAP PEREKONOMIAN DI PROVINSI JAMBI
}

\author{
oleh: \\ *) Ali Fahmi, S.E., M.E. \\ *) Dosen Tetap STIE Muhahammadiyah Jambi \\ E-mail: alifahmi1969@yahoo.com
}

\begin{abstract}
Abstrak
Penelitian ini bertujuan untuk melihat seberapa besar pengaruh belanja langsung terhadap perekonomian Provinsi Jambi dalam hal ini. Data yang digunakan dalam penelitian ini adalah data sekunder yang diperoleh dari kantorPemerintah Provinsi Jambi dan Kantor Statistik Provinsi Jambi periode 2005-2015. Metode analisis yang digunakan adalah Regresi Berganda. Hasil analisis sacara parsial belanja Barang dan Jasa serta belanja modal berpegaruh secara singnifikan terhadap Perekonomian Provinsi Jambi. Hasil dari penelitian secara simultan menunjukkan bahwa belanja pegawai, Barang dan jasa serta belanja modal berpengaruh secara signifikan terhadap Pertumbuhan kinerja keuangan (PDRB) Provinsi Jambi.
\end{abstract}

Kata Kunci: Belanja Langsung (Belanja Pegawai, Barang dan Jasa serta Belanja Modal), Produk Domestik Regional Bruto Provinsi Jambi

\section{Pendahuluan}

Pada dasarnya tentu setiap daerah akan berusaha menaikkan pertumbuhan ekonomi setinggi mungkin. Karena dengan terjadi kenaikkan pertumbuhan ekonomi berarti salah satu indicator pembangunan ekonomi mengalami kenaikan yang berarti juga terjadi pengaruh positif pada pembangunan ekonomi sendiri. Kenaikan pembangunan ekonomi pun akan meningkatkan kemakmuran dan kesejahteraan masyarakat.Menurut Boediono (1981) pertumbuhan ekonomi adalah adalah proses kenaikan output perkapita dalam jangka panjang. Sedangkan menurut Case dan Fair (2006), pertumbuhan ekonomi diartikan peningkatan total output suatu perekonomian.

Pembangunan ekonomi salah satu aspek yang menjadi prioritas dalam pembangunan, ketimpangan sosial ekonomi melahirkan kecemburuan sosial yang pada akhirnya akan berakibat timbul berbagai tindak criminal.

Percepatan pembangunan ekonomi merupakan alternatif dan salah satu solusi pemecahan masalah tersebut dan untuk mempercepat pembangunan ekonomi tersebut diperlukan pembiayaan pembangunan yang bertumpu kepada Anggaran Pendapatan dan Belanja Negara (APBN). 
Dalam konteks diberlakukannya Undang-Undang Nomor 32 Tahun 2004 yang merupakan revisi dari Undang-Undang Nomor 22 Tahun 1999, tentang pemerintahan daerah, maka pembangunan daerah otonomi harus bertumpu pada kekuatan dan kemampuan potensi yang dimiliki daerah itu sendiri.

Otonomi daerah yang hakekatnya memberikan peluang yang lebih besar kepada daerah untuk mengoptimalkan potensi yang dimiliki daerah, baik yang menyangkut sumber daya manusia, dana maupun sumber daya lain yang merupakan kekayaan daerah. Menurut Undangundang No. 32 tahun 2004 dan Undang-undang No. 33 Tahun 2004 dengan otonomi daerah, pemerintah daerah diharapkan semakin mandiri, mengurangi ketergantungan terhadap pemerintah pusat, baik dalam hal pembiayaan pembangunan maupun dalam hal pengelolaan keuangan daerah.

Pembangunan daerah tidak mungkin diwujudkan tanpa adanya pembangunan fisik berupa sarana dan prasarana. Pembangunan fisik tersebut dapat dilaksanakan jika perencanaannya dimasukkan dalam APBD pada pos belanja, khususnya belanja modal.

Belanja modal pada umumnya dialokasikan untuk perolehan asset tetap yang dapat digunakan sebagai sarana pembangunan daerah. Alokasi belanja modal dibentuk melalui proses penyusunan anggaran. Tentunya dalam pengalokasian belanja modal sebagai pendukung proses pembangunan, peran proses penganggaran sangatlah signifikan. Penggunaan pendekatan penganggaran berbasis kinerja tentunya akan semakin berpengaruh dalam penetapan tujuan dan outcome hingga akhirnya dijelaskan kedalam angka-angka pada pos belanja modal APBD.

Belanja Daerah atau pengeluaran pemerintah daerah dalam bentuk Belanja Tidak Langsung dan Belanja Langsung telah turut memberikan sumbangsih yang cukup besar terhadap pembangunan Provinsi Jambi

Pemerintah menyerahkan sepenuhnya berbagai kebijakan pembangunan daerah termasuk dalam mengalokasikan anggaran pembangunan, dengan meningkatnya pengeluaran pemerintah maka diharapkan kegiatan perekonomian di daerah semakin terpacu.

Begitu juga di Provinsi Jambi hal ini tercermin dari meningkatnya PDRB dari tahun ketahun. Alokasi belanja pemerintah sendiri terbagi menjadi alokasi belanja langsung dan alokasi belanja tidak langsung.

Alokasi belanja tidak langsung adalah alokasi belanja yang berkaitan dengan kegiatan atau program yang ada pada Satuan Kerja Perangkat Daerah (SKPD), yaitu; Belanja Pegawai, bunga, subsidi, hibah, bantuan sosial, belanja bagi hasil dan bantuan keuangan, dan belanja tidak terduga. 
Adapun Belanja Langsung adalah; Belanja Pegawai, belanja barang dan jasa, dan Belanja modal. Meningkatnya alokasi belanja langsung akan mendorong penyediaan sarana dan prasarana kegiatan ekonomi yang diperlukan masyarakat.

\section{Metode Penelitian}

Metode Penelitian yang digunakan dalam penelitian ini adalah metode Deskriptif dan metode Kuantitatif dengan menggunakan data sekunder.

\section{Model Analisis Pertama}

Untuk menghitung dan menganalisis pertumbuhan ekonomi digunakan digunakan rumus :

$$
G=\frac{\left(P_{n}-P_{n-1}\right)}{P_{n-1}} \quad X 100 \%
$$

Dimana:

$\mathrm{G} \quad=$ Pertumbuhan tahun ke-n

$\mathrm{P}_{\mathrm{n}} \quad=$ Data Tahun ke $-\mathrm{n}$

$\mathrm{P}_{\mathrm{n}-1} \quad=$ Data tahun awal

Untuk menghitung kontribusi digunakan rumus Sebagai berikut

$$
\mathrm{K}=\frac{\mathrm{BP} / \mathrm{BBKJ} / \mathrm{BM}}{\mathrm{BL}} \times 100 \%
$$

Dimana:

$\begin{array}{ll}\mathrm{BP} & =\text { Belanja Pegawai } \\ \mathrm{BBJ} & =\text { Belanja Barang dan Jasa } \\ \mathrm{BM} & =\text { Belanja Modal } \\ \mathrm{BL} & =\text { Belanja Langsung }\end{array}$

Model Analis Kedua

Untuk menganalisis besar dan pengaruh belanja langsung terhadap PDRB Provinsi Jambi, maka digunakan Model Regresi Berganda dengan formula :

$\mathrm{Y}=\beta_{0}+\beta_{1} \mathrm{BP}+\beta_{2} \mathrm{BBJ}+\beta_{3} \mathrm{BM}+\mathrm{ei}$

Dimana :

$\mathrm{Y}=$ PDRB Provinsi Jambi

$\beta_{0} \quad=$ Konstanta

$\beta_{1-3}=$ Koofisien regresi

$\mathrm{X}_{1} \quad=$ Belanja Pegawai

$\mathrm{X}_{2} \quad=$ Belanja Barang dan Jasa

$\mathrm{X}_{3} \quad=$ Belanja Modal

ei $\quad=$ Error term (Kesalahan Pengganggu) 


\section{Pengujian Hipotesis}

Untuk menguji hipotesis penelitian dilakukan pengujian secara statistik sebagai berikut:

\section{Uji F}

Uji F menunjukkan bahwa secara bersama-sama (simultan) semua variabel independen mempengaruhi variabel dependen, digunakan uji $\mathrm{F}$ yang didapat dari rumus :

$$
F=\frac{R^{2} / k}{1-R^{2} /(n-k-1)} \quad \text { (Gujarati, 2003: 939) }
$$

Ket :

$\mathrm{R}^{2} \quad=$ koefisien determinasi

$\mathrm{N} \quad=$ ukuran sampel

$\mathrm{K} \quad$ = Banyaknya variabel bebas

Untuk uji F, kriteri uji yang dipakai adalah :

- $\mathrm{H}_{0}$ diterima bila $\mathrm{F} \leq \mathrm{F} \alpha$

- $\mathrm{H}_{0}$ ditolak bila $\mathrm{F}>\mathrm{F} \alpha$

$\mathrm{F}_{\alpha}$ ditentukan oleh degree of freedom pembilang dan penyebut yaitu $\mathrm{V}_{1}=\mathrm{k}$ dan $\mathrm{V}_{2}=\mathrm{n}$ k- 1. Bila $\mathrm{H}_{0}$ diterima, maka diartikan sebagai tidak signifikannya suatu pengaruh dari variabelvariabel independen secara bersama-sama atas suatu variabel dependen dan penolakan $\mathrm{H}_{0}$ menunjukan adanya pengaruh yang signifikan dari variabel-variabel independen secara bersama-sama terhadap suatu variabel independen.

\section{Uji t}

Untuk mengetahui apakah koefesien korelasi parsial bermakna dipergunakan uji uji regresi secara parsial yaitu dengan rumus :

$$
\mathrm{t}_{\alpha \text { itung }}=\frac{\mathrm{b}-\beta}{\mathrm{sb}} \quad \text { (Gujarati, 2003: 938) }
$$

Berdasarkan pengujian uji t, akan diperoleh hasil t hitung. Kemudian dibandingkan dengan t table. Keputusan yang akan diambil adalah:

O Terima Ho jika $-\mathrm{t}(1-1 / 2 \alpha) \leq \mathrm{t} \leq \mathrm{t}\left(1-\frac{1 / 2}{2}\right)$

O Tolak Ho jika $\mathrm{t}<-\mathrm{t}(1-1 / 2 \alpha \alpha)$ atau $\mathrm{t}>\mathrm{t}(1-1 / 2 \alpha)$

Pengujian hipotesis dilakukan dengan uji dua pihak pada taraf signifikansi yang digunakan $5 \%$ dan $\mathrm{dk}=\mathrm{n}-\mathrm{k}-1$

Bila H0 ditolak dan sebaliknya H1 di terima artinya bahwa variabel bebas tersebut berpengaruh signifikan terhadap variabel terikat. 


\section{Hasil Penelitian dan Pembahasan}

\section{Perhitungan PDRB}

Kondisi pertumbuhan ekonomi diketahui melalui jumlah kenaikan output dalam jangka panjang.Jika dalam suatu negara hal yang bisa menunjukkan pertumbuhan ekonomi atau kinerja ekonomi melalui progres dari Produk Domestik Bruto (PDB) maka jika berlaku di suatu daerah yang diperhatikan adalah PDRB perkapita. Ini seperti penyataan Rachmawati (2009) Kondisi perekonomian suatu daerah tercermin dalam Produk Domestik Regional Bruto (PDRB).

Selanjutnya Djoyohadikusumo (2004) menyatakan PDRB merupakan jumlah keseluruhan produk yang dihasilkan suatu wilayah selama satu periode dimana jumlah barang-barang dan jasa yang dihasilkan tersebut dinilai dengan uang atas harga pasar yang sedang berjalan. Jadi pada umumnya perhitungan pendapatan regional didasarkan pada harga berlaku, inflasi belum dieleminir sehingga kenaikan pendapatan yang diterima oleh faktor-faktor produksi dari waktu ke waktu belum tentu kenaikan riil. Oleh sebab itu perhitungan pendapatan regional juga dihitung berdasarkan harga konstan guna melihat kenaikan riil dari kenaikan nilai produksi suatu daerah.

Menurut Anonim (2002) ada dua pendekatan dalam perhitungan yaitu metode perhitungan langsung dan tidak langsung. Dalam metode perhitunan secara langsung digunakan data daerah sehingga hasil perhitungannya memperlihatkan produk jasa yang dihasilkan di daerah tersebut. Metode ini dapat dilakukan dengan tiga macam pendekatan yaitu:

\section{Pendekatan produksi}

Dalam menggunakan metode ini dilakukan dengan mengalikan jumlah barang / jasa yang diproduksi seluruh sektor ekonomi dengan harga barang dan jasa tersebut. Nilai tambah barang dan jasa diperoleh dengan mengurangkan biaya antara dari masing-masing output sektor tersebut.

2. Pendekatan Pendapatan

Perhitungan nilai tambah dari setiap kegiatan ekonomi yang diperkirakan dengan menjumlah semua balas jasa faktor produksi, seperti upah dan gaji, surplus usaha, penyusutan dan pajak tak langsung neto. Metode perhitungan ini banyak dilakukan pada sektor yang produksinya berupa jasa. 
3. Pendekatan pengeluaran

Pendekatan dari sisi pengeluaran bertitik tolak pada penggunaan akhir barang dan jasa yang diproduksi di dalam negeri. Pendekatan ini pengeluaran ini digunakan untuk menghitung PDRB menurut sudut penggunaan.

Untuk perhitungan PDRB berdasarkan harga berlaku dengan metode tidak langsung dilakukan dengan perhitungan nilai tambah dengan menggunakan data nasional, yaitu dengan menggunakan metode alokasi. Alokator yang biasa digunakan adalah: Nilai Produksi Bruto/netto, tenaga kerja, penduduk, jumlah produksi dan alokator tidak langsung. Untuk perhitungan PDRB berdasarkan harga konstan digunakan untuk melihat pertumbuhan riill dari tahun ketahun bagi setiap agregat ekonomi. Agregat ekonomi yang dimaksud adalah PDRB, PDRB per kapita.

\section{Perkembangan Produk Domestik Regional Bruto Provinsi Jambi}

Produk Domestik Regional Bruto (PDRB) masih menjadi salah satu indikator dalam menentukan keberhasilan pembangunan suatu daerah dan juga dapat digunakan sebagai indikator guna melihat tingkat kesejahteraan masyarakat pada suatu wilayah. PDRB yang cenderung meningkat menjadi mengindikasikan terjadinya peningkatan pembangunan dan kesejahteraan masyarakat yang terus membaik pula, sebaliknya PDRB yang mengalami grafik menurun mencerminkan terjadinya kemunduran pembangunan dan penurunan tingkat kesejahteraan masyarakat.

Selama periode 2005-2015 PDRB Provinsi Jambi berdasarkan harga konstan tahun 2003 menunjukkan kecenderungan yang meningkat, sebagaimana tergambar pada tabel berikut :

Tabel 1

Perkembangan PDRB Provinsi Jambi Periode 2005-2015 Berdasarkan Harga Konstan Tahun 2010

\begin{tabular}{|c|c|c|}
\hline Tahun & PDRB Provinsi Jambi & Perkembangan (\%) \\
\hline 2005 & 65.290 .593 & - \\
2006 & 69.137 .899 & 5,89 \\
2007 & 73.853 .861 & 6,82 \\
2008 & 79.139 .001 & 7,16 \\
2009 & 84.186 .000 & 6,38 \\
2010 & 90.618 .411 & 7,64 \\
2011 & 97.740 .874 & 7,86 \\
2012 & 104.615 .082 & 7,03 \\
2013 & 11.766 .131 & 6,84 \\
2014 & 119.991 .444 & 7,36 \\
2015 & 125.036 .398 & 4.21 \\
\hline \multicolumn{2}{|c|}{} \\
\hline
\end{tabular}

Sumber: Bappeda Provinsi Jambi, Tahun 2016 
Berdasarkan tabel di atas tergambar bahwa selama periode 2005-2015 PDRB Provinsi Jambi berdasarkan harga konstan tahun 2010 menunjukkan kecenderungan yang meningkat. Peningkatan ini juga mencerminkan bahwa perekonomian di Provinsi Jambi mengalami laju perkembangan yang positif

Dari tabel ini pertumbuhan PDRB berdasarkan harga konstan tertinggi terjadi pada tahun 2011, yaitu sebesar 7,86 persen. Tingginya PDRB disebabkan pemulihan ekonomi yang semakin baik, sedangakan pertumbuhan PDRB terendah terjadi pada tahun 2015, yaitu sebesar 4, persen. Rendahnya pertumbuhan ekonomi pada tahun ini tidak terlepas dari kondisi 20102015 krisis keuangan internasional yang terjadi dipenghujung tahun 2015 sebagai akibat dari krisis keuangan sebagai akibat dari harga minyak yang mengalami koreksi penurunan. Namun secara rata-rata selama periode 2005-2015 pertumbuhan PDRB berdasarkan harga konstan adalah sebesar 6,72 persen.

\section{Belanja Daerah}

Belanja daerah menurut Brojonegoro (2003) adalah semua pengeluaran pemerintah daerah pada suatu periode Anggaran. Anggaran Pendapatan dan Belanja Daerah terdiri dari tiga komponen utama, yaitu unsur penerimaan, belanja rutin dan belanja pembangunan. Ketiga komponen itu meskipun disusun hampir secara bersamaan, akan tetapi proses penyusunannya berada di lembaga yang berbeda.

Berdasarkan Permendagri No. 13 Tahun 2006, belanja menurut kelompok belanja terdiri dari:

1. Belanja tidak langsung

Belanja tidak langsung merupakan belanja yang dianggarkan tidak terkait secara langsung dengan pelaksanaan program dan kegiatan. Kelompok belanja tidak langsung dibagi menurut jenis belanja yang terdiri dari belanja pegawai, bunga, subsudi, hibah, bantuan sosial, belanja bagi hasil, bantuan keuangan, dan belanja tidak terduga.

2. Belanja langsung

Belanja langsung merupakan belanja yang dianggarkan terkait secara langsung dengan pelaksanaan program dan kegiatan, khususnya pembangunan infrastruktur. Kelompok belanja langsung dibagi menurut jenis belanja yang terdiri dari belanja pegawai yang dimaksudkan untuk pengeluaran honorarium/ upah dalam 
melaksanakan program dan kegiatan pemerintah daerah; belanja barang dan jasa; dan belanja modal.

Menurut Permendagri No. 13 Tahun 2006, "Belanja modal digunakan untuk pengeluaran yang dilakukan dalam rangka pembelian/ pengadaan atau pembangunan aset tetap berwujud yang mempunyai nilai manfaat lebih dari 12 bulan untuk digunakan dalam kegiatan pemerintahan, seperti dalam bentuk tanah, peralatan dan mesin, gedung dan bangunan, jalan, irigasi dan jaringan, dan asset tetap lainnya."

Pengeluaran pemerintah daerah adalah seluruh belanja yang telah ditetapkan oleh pemerintah daerah untuk melaksanakan kegiatan pemerintah daerah, baik rutin maupun pembangunan (Sutrisno, 2004). Pengeluaran pemerintah adalah pengeluaran untuk menyediakan fasilitas pendidikan dan kesehatan, pengeluaran untuk menyediakan polisi dan tentara, pengeluaran gaji untuk pegawai pemerintah dan pengeluaran untuk mengembangkan infrastruktur yang dibuat untuk kepentingan masyarakat (Sukirno, 2004).

\section{Perkembangan Belanja Langsung Provinsi Jambi}

Keberhasilan pembangunan suatu daerah sangat ditentukan oleh alokasi belanja langsung. Dana alokasi belanja langsung yang memadai dapat menjamin terlaksananya program-program pembangunan dengan baik.

Tabel 2 Perkembangan Alokasi Belanja Langsung Provinsi Jambi 2005-2015

\begin{tabular}{|c|c|c|}
\hline Tahun & $\begin{array}{c}\text { Alokasi belanja Langsung } \\
(\mathrm{Rp} .000)\end{array}$ & $\begin{array}{c}\text { Pertumbuhan } \\
(\%)\end{array}$ \\
\hline 2005 & 371.956 .994 & - \\
2006 & 663.201 .021 & 78,30 \\
2007 & 778.554 .416 & 17,39 \\
2008 & 893.258 .981 & 14,73 \\
2009 & 844.896 .993 & $(5,41)$ \\
2010 & 815.863 .006 & $(3,44)$ \\
2011 & 989.903 .026 & 21,33 \\
2012 & 1.363 .636 .024 & 37,75 \\
2013 & 1.740 .363 .017 & 27,63 \\
2014 & 1.721 .516 .992 & $(1,08)$ \\
2015 & 1.663 .175 .000 & $(3,39)$ \\
\hline Rata-rata & & 18,38 \\
\hline
\end{tabular}

Sumber: BPS Provinsi Jambi, Tahun 2016

Dari tabel 2 tergambar bahwa selama kurun waktu 2005-2015 belanja langsung pemerintah Provinsi Jambi secara absolut menunjukkan kecenderungan yang meningkat, 
belanja tertinggi di Provinsi Jambi terjadi pada tahun 2013, yaitu sebesar Rp. 1.740.363.000.000, sementara nilai belanja langsung terendah terjadi pada tahun 2005, yaitu sebesar Rp. 371.956.994.000. Sementara Laju pertumbuhan alokasi belanja langsung pemerintah Provinsi Jambi tertinggi terjadi pada tahun 2006, yaitu sebesar $78,30 \%$ atau meningkat hampir dua kali lipat dari tahun 2005. Peningkatan ini menunjukkan pemerintah ini membangun sarana dan prasarana publik seperti jalan dan jembatan menjadi lebih baik dan lebih luas, sedangkan rata-rata selama tahun 2005-2015 laju pertumbuhan belanja langsung pemerintah Provinsi Jambi adalah sebesar 18,38\%.

\section{a. Perkembangan Belanja Pegawai dan Kontribusinya terhadap Belanja Langsung Pemerintah Provinsi Jambi}

Belanja pegawai dalam struktur belanja langsung adalah belanja yang berkaitan dengan honor suatu proyek atau kegiatan. Selama periode 2005-2015 alokasi belanja pegawai menunjukkan kecenderungan yang terus meningkat, sebagaimana tergambar pada tabel 3 berikut ini.

Tabel 3 Perkembangan Belanja Pegawai dan Kontribusinya Terhadap Belanja Langsung Pemerintah Provinsi Jambi Periode 2005-2015

\begin{tabular}{|c|c|c|c|}
\hline Tahun & $\begin{array}{c}\text { Belanja Pegawai } \\
\mathbf{( R p . 0 0 0 )}\end{array}$ & $\begin{array}{c}\text { Perkembangan } \\
(\mathbf{\%})\end{array}$ & Kontribusi (\%) \\
\hline 2005 & 11.784 .580 & - & 3,17 \\
2006 & 16.921 .125 & 43,59 & 2,55 \\
2007 & 67.965 .030 & 301,66 & 8,73 \\
2008 & 54.733 .000 & $(19,47)$ & 6,13 \\
2009 & 50.985 .000 & $(6,85)$ & 6,03 \\
2010 & 53.962 .000 & 5,84 & 6,61 \\
2011 & 68.132 .000 & 26,26 & 6,88 \\
2012 & 84.158 .000 & 23,52 & 6,17 \\
2013 & 98.337 .000 & 16,85 & 5,65 \\
2014 & 90.005 .000 & $(8,47)$ & 5,23 \\
2015 & 110.945 .000 & 23,27 & 7,10 \\
\hline Rata-rata & & 40,62 & 5,55 \\
\hline
\end{tabular}

Sumber: BPS Provinsi Jambi, Tahun 2016

Berdasarkan tabel 3 tergambar perkembangan alokasi belanja pegawai dalam struktur belanja langsung pemerintah Provinsi Jambi yang menunjukkan kecenderungan meningkat. Dimana laju pertumbuhan alokasi belanja pegawai tertinggi terjadi pada tahun 2007, yaitu sebesar 301,66 \%. Tingginya laju pertumbuhan belanja pegawai menunjukkan semakin besarnya proyek pembangunan infrastruktur publik dan kegiatan program pengentasan kemiskinan, sehingga memerlukan alokasi belanja pegawai yang lebih besar 
pula, sementara laju pertumbuhan belanja pegawai terendah terjadi pada tahun 2008, yaitu $-19,47 \%$. Secara rata-rata selama periode 2005-2015 alokasi belanja pegawai dalam struktur belanja langsung pemerintah Provinsi Jambi mengalami peningkatan rata-rata sebesar $40,62 \%$.

\section{b. Perkembangan Belanja Barang dan Jasa Serta Kontribusinya terhadap Belanja}

\section{Langsung Pemerintah Provinsi Jambi}

Belanja barang dan jasa adalah alokasi belanja yang diperuntukkan untuk pembelian barang-barang yang diperlukan untuk kegiatan proyek, seperti belanja kendaraan operasional, belanja alat-alat teknis dan jasa konsultan proyek. Laju pertumbuhan belanja barang dan jasa tertinggi terjadi pada tahun 2006, yaitu sebesar $122,31 \%$, sementara laju pertumbuhan terendah terjadi pada tahun 2015 , yaitu sebesar $18,80 \%$. Secara rata-rata selama periode 2005-2015 rata-rata laju pertumbuhan belanja barang dan jasa pada struktur belanja langsung pemerintah Provinsi Jambi adalah sebesar $25,35 \%$.

Kontribusi tertinggi alokasi belanja barang dan jasa sebesar $47,25 \%$, terjadi pada tahun 2014, sementara kontribusi terendah terjadi pada tahun 2005, yaitu sebesar 27,75\%. Secara rata-rata selama periode 2005-2015 kontribusi belanja barang dan jasa terhadap belanja langsung pemerintah provinsi Jambi adalah sebesar 35,88\%. Untuk jelasnya dapat dilihat Tabel 4 dibawah ini:

Tabel 4 Perkembangan Belanja Barang dan Jasa Serta Kontribusinya Terhadap Belanja Langsung Pemerintah Provinsi Jambi Periode 2005-2015

\begin{tabular}{|c|c|c|c|}
\hline & $\begin{array}{c}\text { Belanja Barang dan } \\
\text { Jasa (Rp.000) }\end{array}$ & Perkembangan (\%) & Kontribusi (\%) \\
\hline 2005 & 103.227 .275 & - & 27,75 \\
2006 & 229.481 .162 & 122,31 & 34,60 \\
2007 & 288.147 .111 & 25,56 & 37,01 \\
2008 & 278.271 .000 & $(3,43)$ & 31,15 \\
2009 & 348.231 .000 & 25,14 & 41,22 \\
2010 & 296.041 .000 & $(14,99)$ & 36,29 \\
2011 & 403.020 .000 & 36,14 & 40,71 \\
2012 & 596.658 .000 & 48,05 & 43,75 \\
2013 & 703.123 .000 & 17,84 & 40,40 \\
2014 & 813.453 .000 & 15,69 & 47,25 \\
2015 & 660.557 .000 & $(18,80)$ & 42,26 \\
\hline Rata-rata & & 25,35 & 35,88 \\
\hline
\end{tabular}

Sumber: BPS Provinsi Jambi, Tahun 2016 


\section{c. Perkembangan Belanja Modal dalam Struktur Belanja Langsung Pemerintah Provinsi Jambi}

Belanja modal dalam struktur belanja langsung adalah belanja yang diperuntukkan untuk kepentingan langsung proyek dan menunjukkan nilai proyek. Belanja modal pada dasarnya merupakan pembelian dari seluruh komponen proyek misalnya untuk proyek pembangunan jalan adalah pembelian aspal, kerikil, pasir, tanah, pembebasan lahan, upah tenaga kerja di lapangan dan biaya lainnya yang terkait secara langsung pelaksanaan kegiatan di lapangan.

Belanja modal memiliki proporsi terbesar dalam alokasi belanja langsung, karena bersinggungan langsung dengan kegiatan suatu proyek. Selama periode 2005-2015 alokasi belanja modal dalam struktur belanja langsung pemerintan Provinsi Jambi menunjukkan kecenderungan yang meningkat, sebagaimana tergambar pada tabel 5 berikut :

\section{Tabel 5 Perkembangan Belanja Modal dan Kontribusinya Terhadap Belanja} Langsung Pemerintah Provinsi Jambi Periode 2005-2015

\begin{tabular}{|c|c|c|c|}
\hline \multicolumn{1}{|l|}{ Tahun } & Belanja Modal & Perkembangan (\%) & Kontribusi (\%) \\
\hline 2005 & 256.945 .139 & - & 69,08 \\
2006 & 416.798 .690 & 62,21 & 62,85 \\
2007 & 422.441 .973 & 1,35 & 54,26 \\
2008 & 560.255 .000 & 32,62 & 62,72 \\
2009 & 445.681 .000 & $(20,45)$ & 52,75 \\
2010 & 465.860 .000 & 4,53 & 57,10 \\
2011 & 518.751 .000 & 11,35 & 52,40 \\
2012 & 682.820 .000 & 31,63 & 50,07 \\
2013 & 938.903 .000 & 37,50 & 53,95 \\
2014 & 818.059 .000 & $(12,87)$ & 47,52 \\
2015 & 791.487 .000 & $(3,25)$ & 50,64 \\
\hline Rata-rata & & 14,46 & 49,48 \\
\hline
\end{tabular}

Sumber: BPS Provinsi Jambi, Tahun 2016

Berdasarkan tabel 5 terlihat bahwa alokasi belanja modal dalam struktur belanja langsung pemerintah Provinsi Jambi menunjukkan kecenderungan yang terus meningkat Laju pertumbuhan belanja modal dalam struktur belanja langsung tertinggi terjadi pada tahun 2006, yaitu sebesar 62,21\%, sementara laju pertumbuhan terendah terjadi pada tahun 2009, yaitu sebesar -20,45. Secara rata-rata selama periode 2005-2015 rata-rata laju pertumbuhan belanja modal adalah sebesar $14,46 \%$. Kontribusi belanja modal terhadap belanja langsung pemerintah Provinsi Jambi tertinggi terjadi pada tahun 2005, yaitu sebesar $69,08 \%$, sementara kontribusi terendah terjadi pada tahun 2014, yaitu sebesar 
47,52\%. Secara rata-rata selama periode 2005-2015 kontribusi belanja modal terhadap belanja langsung pemerintah Provinsi Jambi adalah sebesar 55,76\%.

\section{Pengaruh Belanja Langsung terhadap Pertumbuhan Ekonomi Provinsi Jambi Periode 2005-2015}

Hasil pengujian dengan program pengolahan data statistik SPSS adalah sebagai berikut:

Tabel 6 Nilai-nilai Koefisien Regresi

\begin{tabular}{|c|c|c|c|c|c|c|}
\hline \multicolumn{7}{|c|}{ Coefficients $^{\mathrm{a}}$} \\
\hline \multirow{2}{*}{\multicolumn{2}{|c|}{ Model }} & \multicolumn{2}{|c|}{$\begin{array}{c}\text { Unstandardized } \\
\text { Coefficients }\end{array}$} & \multirow{2}{*}{$\begin{array}{c}\begin{array}{c}\text { Standardized } \\
\text { Coefficients }\end{array} \\
\text { Beta }\end{array}$} & \multirow[t]{2}{*}{$\mathrm{t}$} & \multirow[t]{2}{*}{ Sig. } \\
\hline & & $\mathrm{B}$ & Std. Error & & & \\
\hline \multirow[t]{4}{*}{1} & (Constant) & 9.648 & 1.445 & & 6.677 & .000 \\
\hline & $\mathrm{X} 1$ & .022 & .094 & .071 & .238 & .818 \\
\hline & $\mathrm{X} 2$ & .284 & .091 & .765 & 3.120 & .011 \\
\hline & $\mathrm{X} 3$ & .267 & .067 & .112 & 3.988 & .001 \\
\hline
\end{tabular}

a. Dependent Variable: Y

Berdasarkan Tabel 6 di atas maka dapat disusun persamaan regresi pengaruh Belanja Langsung; ( $\mathrm{X}_{1}=$ Belanja Pegawai, $\mathrm{X}_{2}=$ Belanja barang dan Jasa, $\mathrm{X}_{3}=$ Belanja Modal) terhadap PDRB Provinsi Jambi sebagai berikut :

$$
Y=9,648+0,022 X_{1}+0,284 X_{2}+0,267 X_{3}+e
$$

Interpretasi dari persamaan regresi diatas dapat ditafsirkan :

1. Nilai konstanta sebesar 9,648. Hal ini berarti bahwa jika Jumlah Belanja Pegawai, Belanja barang dan jasa sertaBelanja Modal tetap atau tidak mengalami perubahan, maka jumlah PDRB Provinsi Jambi sebesar nilai konstanta yaitu 9.648 (dalam ribuan).

2. Nilai kofesien bahwa alokasi belanja pegawai (X1) sebesar 0,22. Hal ini mengandung arti bahwa setiap kenaikan alokasi belanja pegawai sebesar 1 persen maka PDRB Provinsi Jambi akan mengalami peningkatan sebesar 0,022 persen.

3. Nilai kofesien bahwa alokasi belanja Barang dan jasa (X2) sebesar 0,284. Hal ini mengandung arti bahwa setiap kenaikan alokasi belanja Barang dan jasa sebesar 1 persen maka PDRB Provinsi Jambi akan mengalami peningkatan sebesar 0,284 persen.

4. Nilai kofesien bahwa alokasi belanja Modal (X3) sebesar 0,267. Hal ini mengandung arti bahwa setiap kenaikan alokasi belanja Modal sebesar 1 persen maka PDRB Provinsi Jambi akan mengalami peningkatan sebesar 0,276 persen. 
Hasil temuan dimana pengaruh komponen belanja langsung adalah positif. Hal ini menunjukkan bahwa Belanja Langsung memberikan dampak terhadap PDRB di Provinsi Jambi.

\section{Pengujian Hipotesis}

\section{Uji F}

Tabal 7

ANOVA ${ }^{b}$

\begin{tabular}{|l|r|r|r|r|r|}
\hline Model & \multicolumn{1}{|c|}{$\begin{array}{c}\text { Sum of } \\
\text { Squares }\end{array}$} & $\mathrm{df}$ & $\begin{array}{c}\text { Mean } \\
\text { Square }\end{array}$ & $\mathrm{F}$ & \multicolumn{1}{c|}{ Sig. } \\
\hline $1 \quad$ Regression & .086 & 1 & .086 & 75.652 & $.000^{\mathrm{a}}$ \\
Residual & .010 & 9 & .001 & & \\
\multicolumn{1}{|c|}{ Total } & .096 & 10 & & & \\
\hline
\end{tabular}

a. Predictors: (Constant), $\mathrm{X}$

b. Dependent Variable: Y

Uji F dipergunakan untuk melihat apakah secara bersama-sama alokasi belanja; pegawai, barang dan jasa serta belanja modal berpengaruh signifikan terhadap PDRB provinsi Jambi. Berdasarkan hasil pengujian Tabel 7 diperoleh nilai $\mathrm{F}$ hitung sebesar 75,652, sementara dengan tingkat keyakinan sebesar 95\%, df $=\mathrm{n}-\mathrm{k}$ diperoleh nilai $\mathrm{F}$ tabel sebesar 4,07, dengan demikian maka nilai $\mathrm{F}$ hitung lebih besar dari nilai $\mathrm{F}$ tabel. Artinya secara bersama-sama alokasi belanja pegawai, belanja barang dan jasa serta alokasi belanja modal berpengaruh positif dan signifikan terhadap PDRB Provinsi Jambi selama periode 2005-2105.

\section{Uji Signifikansi (uji t)}

Uji t dipergunakan untuk melihat apakah secara parsial variabel belanja pegawai, alokasi belanja barang dan jasa serta alokasi belanja modal berpengaruh positif dan signifikan terhadap PDRB Provinsi Jambi.

Tabel 8 Nilai $t$ hitung

\begin{tabular}{|c|r|r|}
\hline Model & t Hitung & Sig. \\
\hline (Constant) & 6.677 & .000 \\
X1 & .238 & .818 \\
X2 & 3.120 & .011 \\
X3 & 3.988 & .001 \\
\hline
\end{tabular}


Interpretasi dari Nilai t hitung sebagai berikut:

1. Pada variabel belanja pegawai sebesar 0,238 . Nilai $t$ tabel dengan tingkat keyakinan sebesar 95\% diperoleh nilai sebesar 1,895. Hal ini menunjukkan bahwa nilai t hitung lebih kecil dari t tabel, maka. Artinya secara parsial belanja pegawai tidak berpengaruh signifikan terhadap pertumbuhan ekonomi di provinsi Jambi.

2. Pada variabel belanja Barang dan jasa sebesar 3,120. Nilai t tabel dengan tingkat keyakinan sebesar 95\% diperoleh nilai sebesar 1,895. Hal ini menunjukkan bahwa nilai $\mathrm{t}$ hitung lebih besar dari t tabel. Artinya secara parsial belanja Barang dan jasa berpengaruh signifikan terhadap pertumbuhan ekonomi di provinsi Jambi.

3. Pada variabel belanja Modal sebesar 3,988. Nilai t tabel dengan tingkat keyakinan sebesar 95\% diperoleh nilai sebesar 1,895. Hal ini menunjukkan bahwa nilai t hitung lebih besar dari t tabel. Artinya secara parsial belanja Modal berpengaruh signifikan terhadap pertumbuhan ekonomi di provinsi Jambi.

Hasil uji t secara parsial belanja barang dan jasa serta variabel belanja modal berpengaruh signifikan terhadap PDRB provinsi Jambi, sementara belanja pegawai tidak berpengaruh signifikan terhadap pertumbuhan ekonomi di provinsi Jambi.

\section{Koefisien Determinasi dan Korelasi}

Berdasarkan hasil pengujian sebagaimana tergambar pada lampiran 2 diperoleh nilai koefisien determinasi sebagai berikut

\section{Tabel 9 Nilai Koefisien Determinasi dan Korelasi}

\begin{tabular}{|l|r|r|r|r|}
\hline Model & $\mathrm{R}$ & R Square & $\begin{array}{c}\text { Adjusted R } \\
\text { Square }\end{array}$ & $\begin{array}{c}\text { Std. Error of the } \\
\text { Estimate }\end{array}$ \\
\hline 1 & $.945^{\mathrm{a}}$ & .894 & .882 & .03369 \\
\hline
\end{tabular}

a. Predictors: (Constant), $\mathrm{X}$

Dari Tabel 9 Nilai koefisien determinasi diperoleh sebesar 0,894. Hal ini dapat ditafsirkan bahwa variasi naik turunnya PDRB Provinsi Jambi mampu dijelaskan oleh; belanja pegawai, belanja barang dan jasa serta belanja modal sebesar 89,4 persen, sementara sisanya sebesar 10,6 persen dijelaskan oleh variabel lainnya yang tidak dimasukkan dalam model penelitian ini. Nilai koefisien korelasi sebesar 0,945 atau mendekati angka 1, hal ini berarti hubungan antara belanja pegawai, belanja barang dan jasa dan belanja modal terhadap PDRB Provinsi Jambi adalah sangat kuat. 


\section{Kesimpulan Dan Saran}

\section{Kesimpulan}

1. Secara rata-rata selama tahun 2005-2015 laju pertumbuhan belanja langsung pemerintah Provinsi Jambi adalah sebesar 18,38\%, sementara alokasi belanja pegawai mengalami peningkatan rata-rata sebesar $40,62 \%$, rata-rata laju pertumbuhan belanja barang sebesar 25,35\%, dan rata-rata laju pertumbuhan belanja modal adalah sebesar 14,46\%. Sedangkan pertumbuhan PDRB berdasarkan harga konstan adalah sebesar 6,72 persen.

2. Hasil Reregresi secara bersama-sama variable; belanja pegawai, belanja barang dan jasa, serta belanja modal berpengaruh dan signifikat terhadap pertumbuhan ekonomi provinsi Jambi, secara parsial varibel belanja barang dan jasa, serta belanja modal berpengaruh dan signifikat terhadap pertumbuhan ekonomi provinsi Jambi. Variabel Independent dapatmenjelaskan 89,4 persen dan nilai kofesien korelasinya sangat tinggi sebesar 94,5 persen.

\section{Saran}

1. Pemerintah Daerah Provinsi Jambi diharapkan dapat meningkatkan pengeluaran pemerintah terutama alokasi belanja langsung guna memperluas pembangunan fasilitas sarana dan prasarana umum di Provinsi Jambi.

2. Pemerintah Daerah Provinsi Jambi hendaknya melakkan alokasi belanja langsung secara tepat untuk meningkan efek multiflier Pembangunan.

\section{DAFTAR PUSTAKA}

Anonim, Garis-garis Besar Haluan Negara 1999, Sinar grafika, Jakarta. , 2016, Perhitungan PDRB Tahun 2010-2015, BPS Provinsi Jambi

Anoraga, Panji 2005, Perusahaan Multinasional dan PMA, Pustaka Jaya, Jakarta

Boediono,2002, Ekonomi Makro (Seri Sinopsis), BP FE-UGM, Yokyakarta

Boediono,1981, Teori Pertumbuhan Ekonomi, BP FE-UGM, Yokyakarta

Dumairy, 2001, Perekonomian Indonesia, Penerbit Salemba Empat. Jakarta

Djoyohadikusumo, Soemitro, 2004, Ekonomi Pembangunan, PT. Pembangunan, Jakarta. 
Dornbusch dan Fisher, 2001, Ekonomi Makro, terjemahan. Penerbit Ghalia Indonesia. Jakarta

Esmara, Hendra, 2004, Teori Ekonomi dan Kebijaksanaan Pembangunan, Gramedia, Jakarta

Gill, Richard, T, 20033, Ekonomi Pembangunan Dulu dan Sekarang, Ghalia Indonesia, Jakarta

Gujarati, Damodar, 2003, Priciple Econometrics. Terjemahan Penerbit Ghalia Indonesia, Jakarta

Guritno Mangkusoebroto, 2002, Ekonomi Publik, BPFE- UGM, yokyakarta.

Koencoro, Mudrajad, 2000, Ekonomi Pembangunan, Teori, Masalah dan Kebijakan, UPP YKPN, Yogyakarta

Partadirejda, 2003, Ekonomika Pembangunan, BP FE-UGM, Yogyakarta

Sukirno, Sadono, 2002, Ekonomi Pembangunan, LP FE- UI, Jakarta , 2004, Ekonomi Makro, Badan Penerbit FE UI, Jakarta

Soeparmoko, 2001, Ekonomika Pembangunan, BP FE-UGM, Yogyakarta

Singarimbun, Masri, 2000 , Metode penelitian survey, BP FE UGM, Yokyakarta.

Supranto, J, 2004, Statistik Induktif, BP FE-UGM, Yogyakarta

Todaro, MP, 2003, Ekonomi di Dunia Ketiga, Ghalia Indonesia, Jakarta

Wijaya, Faried, 2001, Ekonomika Makro, BP FE UI, Jakarta

Winardi, 2000. Kamus Ekonomi, Mandar Maju, Jakarta 